\title{
Functional diversity of macrophyte communities within and between Pyrenean lakes
}

\author{
Esperança GACIA*, Eglantine CHAPPUIS, Ana LUMBRERAS, Joan L. RIERA ${ }^{1)}$ and Enric BALLESTEROS \\ Centre d'Estudis Avançats de Blanes, CSIC, Ctra. Accés Cala St. Francesc 14, 17300 Blanes, Spain \\ ${ }^{1)}$ Dept. Ecologia, Univ. Barcelona, Av. Diagonal 645, 08028 Barcelona, Spain \\ *e-mail corrresponding author: gacia@ceab.csic.es
}

\begin{abstract}
Submersed vegetation is a common feature in about 70\% Pyrenean high mountain (>1500 $\mathrm{m}$ a.s.l.) lakes. Isoetids and soft-water elodeids are common elements of this underwater flora and can form distinct vegetation units (i.e. patches of vegetation dominated by different species) within complex mosaics of vegetation in shallow waters $(<7 \mathrm{~m})$. Since isoetids exert a strong influence on sediment biogeochemistry due to high radial oxygen loss, we examined the small scale characteristics of the lake environment (water and sediment) associated to vegetation patches in order to ascertain potential functional differences among them. To do so, we characterised the species composition and biomass of the main vegetation units from 11 lakes, defined plant communities based on biomass data, and then related each community with sediment properties (redox and dissolved nutrient concentration in the pore water) and water nutrient concentration within plant canopy. We also characterised lake water and sediment in areas without vegetation as a reference. A total of twenty-one vegetation units were identified, ranging from one to five per lake. A cluster analysis on biomass species composition suggested seven different macrophyte communities that were named after the most dominant species: Nitella sp., Potamogeton praelongus, Myriophyllum alterniflorum, Sparganium angustifolium, Isoetes echinospora, Isoetes lacustris and Carex rostrata. Coupling between macrophyte communities and their immediate environment (overlying water and sediment) was manifested mainly as variation in sediment redox conditions and the dominant form of inorganic nitrogen in pore-water. These effects depended on the specific composition of the community, and on the allocation between above-and belowground biomass, and could be predicted with a model relating the average and standard deviation of sediment redox potential from 0 down to $-20 \mathrm{~cm}$, across macrophyte communities. Differences in pore-water total dissolved phosphorus were related to the trophic state of the lakes. There was no correlation between sediment and water column dissolved nutrients. However, nitrate concentrations tended to be lower in the water overlaying isoetid communities, in apparent contradiction to the patterns of dissolved nitrates in the pore-water. These tendencies were robust even when comparing the water overlaying communities within the same lake, thus pointing towards a potential effect of isoetids in reducing dissolved nitrogen in the lakes.
\end{abstract}

Key words: Macrophytes, soft-water lakes, sediment redox, nutrients, Pyrenees

\section{INTRODUCTION}

Pyrenean lakes are high mountain (>1500 m a.s.l.) alpine lakes with oligotrophic soft-waters (Catalan et al. 1993; Mosello et al. 2002). Submersed vegetation is present in about $70 \%$ of these lakes and is characterised by species-poor communities with a prevalence of isoetids (Gacia et al. 1994). The isoetid flora of the Pyrenees is relatively poor compared to that of Central and North European lakes (see revision in Murphy 2002) having as main representatives two species of the genus Isoetes (i.e., I. lacustris and I. echinospora). Aside from isoetids, other components of the macrophyte flora of these lakes are soft-water submersed elodeids (i.e., Myriophyllum alterniflorum and species of the genus Nitella, Potamogeton and Ranunculus) and rooted floating-leaf species (i.e., S. angustifolium, Callitriche palustris, Ranunculus and Potamogeton species; Margalef Mir 1981; Gacia et al. 1994).

Macrophytes in Pyrenean lakes are distributed along gradients of altitude, water column chemistry (i.e., alkalinity and conductivity), and nutrient concentration.
The isoetids (I. lacustris, I. echinospora, Subularia aquatica, Eleocharis acicularis) plus accompanying species (Sparganium angustifolium, Nitella sp.) are indicative of extreme soft-water and ultra-oligotrophic (total phosphorus $<5 \mu \mathrm{M} \mathrm{L}^{-1}$ ) conditions, while elodeids are more abundant in waters with relatively higher mineral content (but still within the range of soft-water conditions). Only a few species are found in mesotrophic shallow pools with cattle influence (Potamogeton natans, Callitriche palustris), while lakes above $2400 \mathrm{~m}$ have only bryophytes (Gacia et al. 1994).

Water chemistry and basin conditions explain a relatively low percentage of the variation in macrophyte presence/absence data (30\% in a redundancy analysis, see Gacia et al. 1994), and species that are presumably indicative of relatively contrasting water chemistry within the Pyrenean context can occur within the same lake (Chappuis et al. 2008). Knowing that the history plays an important role in determining lakes macrophyte community composition (Farmer \& Adams 1989), it seems that plant-ambient interactions should be investigated further than in relation to water chemistry. In par- 
ticular, the relationship between macrophyte community composition and sediment properties should be taken into consideration (Janauer 2001), especially when it comes to isoetid species because they exert a strong influence on sediment biogeochemistry due to high radial oxygen loss (Sand Jensen et al. 1982; Pedersen et al. 1995).

In Central Europe, extensive correlative analyses have revealed the main environmental characteristics associated to lakes with isoetids, which result both from their habitat requirements and from their engineering capacity on the sediment (Smolders et al. 2002). Yet, to our knowledge, little work has been done in order to ascertain the importance of oxygen root leaking in isoetid species for the sediment-water column nutrient exchange. Only in Lake Kvrie (Denmark) Olsen \& Andersen (1994) studied seasonal and diurnal cycles of in situ fluxes of sediment-water dissolved nitrogen exchange in areas with and without the isoetid Littorella uniflora. Their results showed no major differences in dissolved nitrogen release from the sediment in the presence of $L$. uniflora compared to areas without vegetation in spite of rather different nitrate concentrations in sediment pore-waters.

In the Pyrenees, the existence of rather developed and productive isoetid communities (Gacia \& Ballesteros 1994) mixed within complex mosaics of vegetation (Chappuis et al. 2008) has led us to examine the small scale characteristics of the lake environment (water and sediment) associated to macrophyte vegetation in order to ascertain potential functional differences associated to vegetation patches. This question seems particularly relevant in the Pyrenees were lakes are small (Camarero et al., in press) and biomass and macrophyte production lie within the highest range for soft-water species (Gacia \& Ballesteros 1994).

Understanding possible functional diversity (Heino 2005) associated to macrophyte diversity in high mountain Pyrenean systems should be of major interest when approaching biology and ecology of other faunal groups, particularly when it comes to benthic animals (Sagova et al. 1993) and for the management of these pristine and endangered systems. Mounting water demand in the Mediterranean region, exacerbated by global climate change and compounded by tourism development in the mountain areas themselves, have increased the demand for water exploitation in the high mountain district, and several small soft-water lakes have already been impacted (Gacia \& Ballesteros 1996). Impoundment and water extraction in these small pristine lakes has been shown to be catastrophic for macrophyte communities, producing massive mortality of vegetation and complete shifts in the species composition (Gacia \& Ballesteros 1998). Thus, studies of the importance of the different macrophyte assemblages for the dynamics of soft-water Pyrenean systems are necessary before any further management actions are taken.
The aim of this work was to study whether species composition was associated to differences in sediment geochemistry and water column solutes in different macrophyte communities from within and between a set of 11 Pyrenean lakes. To do so, we identified patches of macrophytes in the study lakes, characterised their community composition based on biomass data, which is a good ecologically sound parameter to identify macrophyte influence on ecosystem functioning (Engelhardt \& Ritchie 2001) and then related macrophyte communities to sediment properties (redox potential and dissolved nutrient concentration in the pore water) and water nutrient within the plant canopy of each of the previously identified communities. Our final goal was to statistically infer differences in plant-water-sediment nutrient exchange associated to different macrophyte communities.

\section{METHODS}

The study was conducted in 11 small high mountain lakes situated within or adjacent to the Aigüestortes National Park in the Central Pyrenees $\left(42^{\circ} 41^{\prime} \mathrm{N}, 0^{\circ} 59^{\prime} \mathrm{E}\right.$; range of 1600-2323 $\mathrm{m}$ a.s.l.). Lakes were chosen to encompass different typologies (i.e., circus and valley lakes; Catalan et al. 1992) and a wide range of macrophyte species compositions based on a previous survey of macrophytes in Pyrenean lakes (Gacia et al. 1994). Lakes were first visually inspected by a diver to identify the distinct vegetation units, i.e., patches of vegetation with dominance of different macrophyte species. In each of these units, water, sediment and macrophyte samples were collected. In the lakes with a significant area of sediment devoid of vegetation, this was also considered as a sampling unit. Sampling was conducted in August 2005, at the time of maximum macrophyte biomass (Gacia 1993).

Plant samples consisted in the overall biomass collected in three replicated $20 \times 20 \mathrm{~cm}^{2}$ quadrats per vegetation unit. Some small $(<1 \%$ lake surface) or too heterogeneous patches were not considered as sampling units. Water samples were collected from within the plant canopy (or just above the sediment in areas without vegetation) and three sediment corers were collected from the plants' rizosphere. All samples were collected by divers.

Plant biomass was sorted by species and compartments (i.e., above and below ground parts) and the average expressed as grams of dry weight $\left(60^{\circ} \mathrm{C}\right.$ until constant weight) per unit surface area. After comparing the biomass data, we decided to treat the helophyte Carex rostrata separately due to the significantly higher biomass values found for this species. Water column samples were analysed for alkalinity, dissolved inorganic nitrogen $\left(\mathrm{NH}_{4}, \mathrm{NO}_{3}\right.$ and $\left.\mathrm{NO}_{2}\right)$ and total dissolved phosphorus following the protocols compiled in The Molar Project (1999). pH and water conductivity were meas- 
Tab. 1. General characteristics of the study lakes. ID is lake code.

\begin{tabular}{ccccc}
\hline ID & Lake & $\begin{array}{c}\text { Altitude } \\
(\text { m a.s.l. })\end{array}$ & $\begin{array}{c}\text { Lake Area } \\
\text { (ha) }\end{array}$ & $\begin{array}{c}\text { Depth max } \\
(\mathrm{m})\end{array}$ \\
\hline BP & Baciver Petit & 2307 & 0.966 & 2 \\
BD & Bassa de Dellui & 2314 & 0.322 & 1 \\
RO & Bassa del Rosari & 2309 & 0.126 & 1 \\
DP & Dellui Petit & 2315 & 1.082 & 3.5 \\
PU & Pudo & 2208 & 4.885 & 10 \\
GR & Bassa de les Granotes & 2323 & 0.740 & 3.5 \\
LL & Llebreta & 1620 & 8.387 & 11.5 \\
LG & Llong & 2000 & 7.409 & 12.5 \\
RD & Redó & 2114 & 6.343 & 11 \\
TR & Trescuro de Dalt & 2044 & 0.907 & 4 \\
XC & Xic & 2228 & 0.724 & 5 \\
\hline
\end{tabular}

ured in situ with an Orion electrode mod. 231 and PTI10 conductivity meter, respectively.

Sediment corers consisted on PVC tubes of $6 \mathrm{~cm}$ in diameter and $30 \mathrm{~cm}$ in length. Two of the three corers had two longitudinal series of holes separated $4 \mathrm{~cm}$ from each other to allow the lateral insertion of electrodes. The two series of holes were displaced $2 \mathrm{~cm}$ from each other to complete a series of redox readings at $2 \mathrm{~cm}$ intervals. The holes were sealed and progressively opened to measure sediment redox potential profiles from the surface down to $20 \mathrm{~cm}$ depth (see Enriquez et al. 2001). Redox potentials were measured in the field right after sediment collection with a Crison electrode coupled to a portable pH-metre (Crison 507) calibrated with a standard solution (Crison $468 \mathrm{mV}$ at $25^{\circ} \mathrm{C}$ ). Measures were made as close to midday as possible to reduce the variance associated with potential daily fluctuations. A third core was kept intact to be sectioned into $2 \mathrm{~cm}$ horizons under and $\mathrm{N}_{2}$ atmosphere to later extract the interstitial water. The protocol for pore-water extraction consisted in freezing and later melting, centrifuging and decanting the water (Levat et al. 1990), which was analysed for dissolved inorganic nitrogen $\left(\mathrm{NH}_{4}, \mathrm{NO}_{3}\right.$ and $\left.\mathrm{NO}_{2}\right)$ and dissolved phosphorous. In Lake Pudo, we were unable to sample sediment corers below the Potamogeton praelongus community, and thus we only provide biomass data.

\subsection{Statistical analysis}

Affinities among the vegetation units identified in the field (i.e., patches of vegetation with dominance of different macrophyte species) were assessed by running a hierarchical cluster analysis (mode group average) on biomass data using the statistical package Primer v. 6 (Mc Clarke \& Gorley 2006). On the resulting set of groups we defined the macrophyte communities and further tested for statistical differences in the partial (above- and belowground) and total macrophyte biomass samples, dissolved nutrient concentration in the sediment pore-water, sediment redox and water column nutrient content using ANOVA. Since communities and lakes were not crossed, we could not check for interaction effects between the lakes and communities on bio- mass or nutrient concentrations. Assumptions of normality (Chi-square test) and heterocedasticity (Cochran's test) were checked and data log-transformed as needed.

To examine the dissimilarity in nutrient concentrations (water column and sediment) among the different plant communities and lakes, we used multidimensional scaling (MDS, PRIMER v. 6). Differences within groups were then tested using ANOSIM (PRIMER v. 6).

The relation between macrophyte biomass and sediment redox potential was assessed by regression analysis with mean sediment redox. This was defined as the mean redox from 0 down to $20 \mathrm{~cm}$ depth averaged among the two replicate corers per vegetation unit. Coupling of dissolved nutrient concentration in the water column and sediment pore-water was also assessed using regression analysis with the former as the independent factor.

\section{RESULTS:}

\subsection{Lake characteristics}

With the exception of Lake Llebreta, the study lakes were situated above $2000 \mathrm{~m}$ a.s.l. (Tab. 1). They were generally small and shallow (Tab. 1) soft-water systems ranging from ultra-oligotrophic to oligotrophic (following Wetzel 2001; Tab. 2). The number of macrophyte species per lake varied from a minimum of 2 to a maximum of 6 , with mean values of 2.8 and a median of 2.5 species per lake. In total, 14 species were recorded (Tab. 3). The percentage of the lake area covered by vegetation was always more than $80 \%$.

\subsection{Vegetation units}

Twenty vegetation units were sampled, ranging from one (i.e., Bassa Dellui and Bassa Rosari de Baciver) to five (L. Xic) within the same lake (Tab. 3). A cluster analysis allowed us to distinguish seven different groups (cutting edge at $40 \%$ similarity; Fig. 1) among the vegetation units. These groups, hereafter referred to as communities, were named after the most dominant species: Nitella sp., Potamogeton praelongus, Myriophyllum alterniflorum, Sparganium angustifolium, Isoetes echinospora, Carex rostrata, and Isoetes lacustris. 
Tab. 2. Water chemical composition of the study lakes. Data are averages of samples collected within the canopy of each of the plant communities plus areas without vegetation within each lake. Values in each cell are mean and standard deviation (above, in parenthesis), and range (below, in brackets). TDP $=$ total dissolved phosphorus); $\mathrm{DOC}=$ dissolved organic carbon.

\begin{tabular}{|c|c|c|c|c|c|c|}
\hline Lake & $\begin{array}{c}\text { TDP } \\
\left.\text { (neq L } L^{-1}\right)\end{array}$ & $\begin{array}{c}\mathrm{NO}_{3} \\
\left(\mu \mathrm{eq} \mathrm{L}{ }^{-1}\right)\end{array}$ & $\begin{array}{c}\mathrm{NH}_{4} \\
\left(\mu \mathrm{eq} \mathrm{L} \mathrm{L}^{-1}\right)\end{array}$ & $\begin{array}{c}\text { DOC } \\
\left(\mathrm{mg} \mathrm{L}^{-1}\right)\end{array}$ & $\begin{array}{l}\text { Alkalinity } \\
\left(\mu \mathrm{eq} \mathrm{L} \mathrm{L}^{-1}\right)\end{array}$ & $\begin{array}{c}\mathrm{Ca} \\
\left(\mu \mathrm{eq} \mathrm{L} \mathrm{L}^{-1}\right)\end{array}$ \\
\hline Baciver Petit & $\begin{array}{c}174.4(1.2) \\
{[173.6-175.3]}\end{array}$ & $\begin{array}{c}3.59(0.44) \\
{[3.28-3.91]}\end{array}$ & $\begin{array}{c}1.54(0.22) \\
{[1.38-1.69]}\end{array}$ & $\begin{array}{c}3.92(1.54) \\
{[2.84-5.01]}\end{array}$ & $\begin{array}{l}59(2.8) \\
{[57-61]}\end{array}$ & $\begin{array}{c}58.5(1) \\
{[57.8-59.2]}\end{array}$ \\
\hline Bassa Dellui & $\begin{array}{c}158.3 \\
-\end{array}$ & $\begin{array}{c}3.56 \\
-\end{array}$ & $\begin{array}{c}3.49 \\
-\end{array}$ & $\begin{array}{c}2.69 \\
-\end{array}$ & $\begin{array}{c}255 \\
-\end{array}$ & $\begin{array}{c}256.2 \\
-\end{array}$ \\
\hline Granotes & $\begin{array}{c}47.9(0.3) \\
{[47.7-48.1]}\end{array}$ & $\begin{array}{c}1.12(0) \\
-\end{array}$ & $\begin{array}{l}0.26(0.05) \\
{[0.22-0.3]}\end{array}$ & $\begin{array}{c}5(0.01) \\
{[4.99-5]}\end{array}$ & $\begin{array}{l}28(11.3) \\
{[20-36]}\end{array}$ & $\begin{array}{c}46.8(0.9) \\
{[46.1-47.5]}\end{array}$ \\
\hline Rosari Baciver & $\begin{array}{c}103 \\
-\end{array}$ & $\begin{array}{l}2 \\
-\end{array}$ & $\begin{array}{l}0 \\
-\end{array}$ & $\begin{array}{c}3.1 \\
-\end{array}$ & $\begin{array}{c}36 \\
-\end{array}$ & $\begin{array}{c}40.8 \\
-\end{array}$ \\
\hline Dellui Petit & $\begin{array}{c}102.6(18.3) \\
{[89.7-115.6]}\end{array}$ & $\begin{array}{c}1.72(0.84) \\
{[1.12-2.31]}\end{array}$ & $\begin{array}{c}1.73(0.12) \\
{[1.65-1.82]}\end{array}$ & $\begin{array}{c}2.21(0.23) \\
{[2.05-2.38]}\end{array}$ & $\begin{array}{c}178(0.7) \\
{[177-178]}\end{array}$ & $\begin{array}{c}191.6(14.6) \\
{[181.2-201.9]}\end{array}$ \\
\hline Llebreta & $\begin{array}{c}95.3(45.2) \\
{[60.3-170.7]}\end{array}$ & $\begin{array}{c}12.28(2.6) \\
{[7.75-13.99]}\end{array}$ & $\begin{array}{l}0.68(0.44) \\
{[0.2-1.4]}\end{array}$ & $\begin{array}{c}1.58(0.47) \\
{[1.18-2.13]}\end{array}$ & $\begin{array}{c}255(5.8) \\
{[250-265]}\end{array}$ & $\begin{array}{c}234(14.2) \\
{[220.5-255.1]}\end{array}$ \\
\hline Llong & $\begin{array}{c}80.1(1.3) \\
{[78.9-81.5]}\end{array}$ & $\begin{array}{c}7.13(0.25) \\
{[6.85-7.31]}\end{array}$ & $\begin{array}{c}0.92(0.04) \\
{[0.88-0.96]}\end{array}$ & $\begin{array}{c}1.44(0.15) \\
{[1.27-1.54]}\end{array}$ & $\begin{array}{c}170(1.7) \\
{[169-172]}\end{array}$ & $\begin{array}{c}158.6(9.3) \\
{[148-165.5]}\end{array}$ \\
\hline Pudo & $\begin{array}{c}257.3(57.1) \\
{[216.9-297.7]}\end{array}$ & $\begin{array}{c}5.1(5.62) \\
{[1.12-9.07]}\end{array}$ & $\begin{array}{c}0.53(0.56) \\
{[0.13-0.92]}\end{array}$ & $\begin{array}{c}1.48(0.46) \\
{[1.16-1.81]}\end{array}$ & $\begin{array}{c}558(49.5) \\
{[523-593]}\end{array}$ & $\begin{array}{c}398.7(42.4) \\
{[368.7-428.7]}\end{array}$ \\
\hline Redo & $\begin{array}{c}58.3(6.8) \\
{[53.6-63.1]}\end{array}$ & $\begin{array}{c}8.86(0.61) \\
{[8.43-9.29]}\end{array}$ & $\begin{array}{c}0.38(0.02) \\
{[0.36-0.39]}\end{array}$ & $\begin{array}{c}1.09(0.38) \\
{[0.82-1.36]}\end{array}$ & $\begin{array}{l}59(2.8) \\
{[57-61]}\end{array}$ & $\begin{array}{c}56.2(1.9) \\
{[54.9-57.5]}\end{array}$ \\
\hline Trescuro Dalt & $\begin{array}{c}112(18.2) \\
{[92.2-128.1]}\end{array}$ & $\begin{array}{c}1.12(0) \\
-\end{array}$ & $\begin{array}{c}0.42(0.05) \\
{[0.36-0.45]}\end{array}$ & $\begin{array}{c}4.22(0.51) \\
{[3.74-4.75]}\end{array}$ & $\begin{array}{c}289(1) \\
{[288-290]}\end{array}$ & $\begin{array}{c}242.7(8.1) \\
{[238-252.1]}\end{array}$ \\
\hline Xic & $\begin{array}{c}89.4(4.4) \\
{[83.2-94.6]}\end{array}$ & $\begin{array}{c}7.1(0.41) \\
{[6.49-7.63]}\end{array}$ & $\begin{array}{l}0.76(0.16) \\
{[0.5-0.92]}\end{array}$ & $\begin{array}{c}1.16(0.07) \\
{[1.08-1.25]}\end{array}$ & $\begin{array}{c}235(5.3) \\
{[226-239]}\end{array}$ & $\begin{array}{c}218.5(23.2) \\
{[193.4-255.3]}\end{array}$ \\
\hline
\end{tabular}

Tab. 3. Macrophyte aboveground biomass sorted by species from the samples collected in each different vegetation unit. Samples are ordered by lake. Data are averages of three replicates expressed as g DW $400 \mathrm{~cm}^{-2}$. Species names are: I.echi=Isoetes echinospora, S.ang=Sparganium angustifolium, S.aqu=Subularia aquatica, I.lac=Isoetes lacustris, C.ros=Carex rostrata, M.alt=Myriophyllum alterniflorum, Nit=Nitella, $\mathrm{P} . \mathrm{ber}=$ Potamogeton berchtoldii, $\mathrm{P}$. alp=Potamogeton alpinus, $\mathrm{P} . \mathrm{per}=$ Potamogeton perfoliatus, P.pra=Potamogeton praelongus, Fil=filamentous algae, J.art=Juncus articulatus, R.tri=Ranunculus trichophyllus ssp. lutulentus.

\begin{tabular}{|c|c|c|c|c|c|c|c|c|c|c|c|c|c|c|c|}
\hline Lake & ID & I.echi & S.ang & S.aqu & I.lac & C.ros & M.alt & Nit & P.ber & P.alp & P.per & P.pra & Fil & J.art & R.tri \\
\hline \multirow[t]{2}{*}{ Baciver Petit } & $\mathrm{BP}$ & 3.06 & 1.28 & 0.06 & 0 & 0 & 0 & 0 & 0 & 0 & 0 & 0 & 0 & 0 & 0 \\
\hline & $\mathrm{BP}$ & 0 & 0 & 0 & 9.77 & 0 & 0 & 0 & 0 & 0 & 0 & 0 & 0 & 0 & 0 \\
\hline Bassa Dellui & $\mathrm{BD}$ & 1.65 & 1.64 & 0.3 & 0 & 0 & 0 & 0 & 0 & 0 & 0 & 0 & 0 & 0 & 0 \\
\hline Bassa Rosari & RO & 0.77 & 0.19 & 0 & 0 & 0 & 0 & 0 & 0 & 0 & 0 & 0 & 0 & 0.16 & 0 \\
\hline Dellui Petit & DP & 0 & 0 & 0.03 & 4.59 & 0 & 0 & 0 & 0 & 0 & 0 & 0 & 0 & 0 & 0 \\
\hline Estany Pudo & $\mathrm{PU}$ & 0 & 0 & 0 & 0 & 0 & 0 & 19.69 & 0 & 0 & 0.83 & 23.64 & 7.54 & 0 & 0 \\
\hline Granotes & GR & 0 & 0 & 0 & 3.64 & 0 & 0 & 0 & 0 & 0 & 0 & 0 & 0 & 0 & 0 \\
\hline \multirow[t]{4}{*}{ Llebreta } & LL & 0 & 0 & 0 & 0 & 92.72 & 0 & 0 & 0 & 0 & 0 & 0 & 0 & 0 & 0 \\
\hline & LL & 0 & 0 & 0 & 0 & 0 & 2.89 & 0.61 & 0.24 & 0 & 0 & 0 & 0 & 0 & 0 \\
\hline & LL & 0 & 0 & 0 & 0 & 0 & 0 & 6.99 & 0 & 0 & 0 & 0 & 0 & 0 & 0 \\
\hline & LL & 0 & 6.96 & 0 & 0 & 0 & 0.71 & 0.45 & 0.1 & 0 & 0 & 0 & 0 & 0 & 0 \\
\hline \multirow[t]{2}{*}{ Llong } & LG & 0 & 0 & 0 & 0 & 0 & 1.95 & 0.2 & 0.06 & 0.34 & 0 & 0 & 0 & 0 & 0 \\
\hline & LG & 0 & 0 & 0 & 0 & 0 & 0 & 3.16 & 0 & 0 & 0 & 0 & 0 & 0 & 0 \\
\hline Redò & $\mathrm{RE}$ & 0 & 0 & 0 & 10.21 & 0 & 0 & 0 & 0 & 0 & 0 & 0 & 0 & 0 & 0 \\
\hline \multirow[t]{2}{*}{ Trescuro } & TR & 0 & 0 & 0 & 0 & 22.22 & 0.51 & 0 & 0 & 0 & 0 & 0 & 0 & 0 & 0 \\
\hline & TR & 0 & 0 & 0 & 0 & 0 & 18.07 & 0 & 0.05 & 0 & 0 & 0 & 0 & 0 & 0 \\
\hline \multirow[t]{5}{*}{ Xic } & $\mathrm{XC}$ & 0 & 0 & 0 & 19.43 & 0 & 0 & 0 & 0.05 & 0 & 0 & 0 & 0 & 0 & 0 \\
\hline & $\mathrm{XC}$ & 0 & 0 & 0 & 0 & 0 & 1.32 & 0.07 & 0 & 2.24 & 0 & 0 & 0 & 0 & 0.18 \\
\hline & $\mathrm{XC}$ & 0 & 0 & 0 & 0 & 0 & 0.01 & 0.81 & 0 & 0 & 0 & 0 & 0 & 0 & 0 \\
\hline & $\mathrm{XC}$ & 0 & 0 & 0 & 0 & 0 & 0 & 0 & 0 & 0 & 0 & 0 & 0 & 0 & 0 \\
\hline & $\mathrm{XC}$ & 0 & 4.29 & 0 & 1.71 & 0 & 0.16 & 0 & 0 & 1.26 & 0 & 0 & 0 & 0 & 0.07 \\
\hline
\end{tabular}




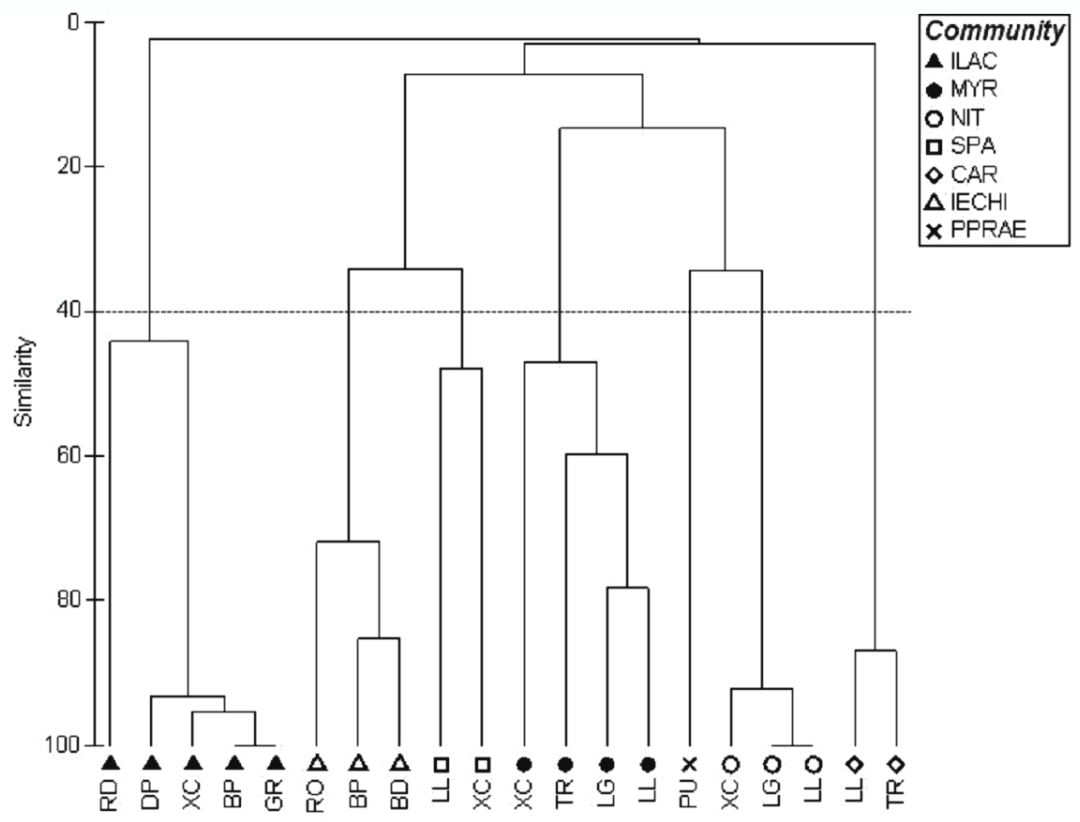

Fig. 1. Cluster analysis of the total biomass data of the macrophyte samples. Lakes follow the identification code given in table 1 . The codes for the identified communities are: ILAC=I. lacustris, IECHI=I. echinospora, SPA=Sparganium, MYR=Myriophyllum, $\mathrm{NIT}=$ Nitella, $\mathrm{CAR}=$ Carex, $\mathrm{PPRAE}=$ Potamogeton praelongus.

The monospecific community of the only helophyte, C. rostrata, stood out from the rest (Fig. 1). The dominance of elodeids characterised three main subgroups, one with the presence of Nitella sp., one with the presence of $M$. alterniflorum, and the community of $P$. praelongus, present only in Lake Pudo. Species of Potamogeton and Ranunculus occurred in some of these communities (Fig. 1; Tab. 3). The presence of I. lacustris, alone or accompanied, characterised another community (Fig. 1). Lastly, two groups merged together with the presence of I. echinospora and the emergent plant $S$. angustifolium (Fig. 1).

\subsection{Biomass of the communities}

Total, aboveground and belowground macrophyte biomass varied significantly between communities and lakes (Figs 2a and b). The helophyte Carex rostrata (with an outlier one order of magnitude higher than the other replicates) was the community with the highest biomass (Tab. 3; Fig. 2a). Among submersed species, the community with $P$. praelongus showed the highest total and aboveground biomass per unit area (Fig. 2a), while the community with I. lacustris had significantly higher belowground biomass compared to the rest (Fig. 2a). The above vs. belowground biomass ratio was significantly higher for the elodeids compared to the isoetids (Fig. 2a).

Macrophyte biomass also varied among lakes, with differences of more than one order of magnitude between systems (Fig. 2b). The highest average value for submersed vegetation was recorded in Lake Pudo followed by lakes Xic and Baciver Petit. The lowest average macrophyte biomass was recorded in lakes Llong and Bassa del Rosari de Baciver (Fig. 2b).

\subsection{Sediment redox potential}

We observed different patterns in the sediment redox profiles of the communities defined above. In bare sediments, redox potentials were negative and did not vary along the profile (Fig. 3a). Two macrophyte communities showed the same pattern of redox potential as sediments without vegetation; these were the community with Nitella (Fig. 3b), an alga, and the community with Myriophyllum alterniflorum (Fig. 3c), a phanerogam with very low underground biomass (Fig. 2a).

In contrast, the sediment of communities containing species of the genus Isoetes showed very positive redox potentials across most of the profiles (Figs $3 \mathrm{~d}$ and e). The capacity for maintaining positive redoxiclines was higher for I. lacustris (down to $18 \mathrm{~cm}$ ) than for I. echinospora (down to $12 \mathrm{~cm}$ ). The Sparganium angustifolium community showed highly variable sediment redox potentials, from strongly reducing to strongly oxidizing conditions (Fig. 3f). These differences occurred when comparing the same community in different lakes because of the eventual presence of species of the genus Isoetes in this mixed community. Lastly, the community of Carex rostrata had sediments with a $4 \mathrm{~cm}$ oxidized superficial layer and then a zone from 4 down to $10 \mathrm{~cm}$ were the redox potential remained close to zero (Fig. 3g). Therefore, in contrast to the elodeid communities, the underground tissue of Carex was able to maintain an intermediate layer with redox potentials more positive than in the absence of vegetation. 

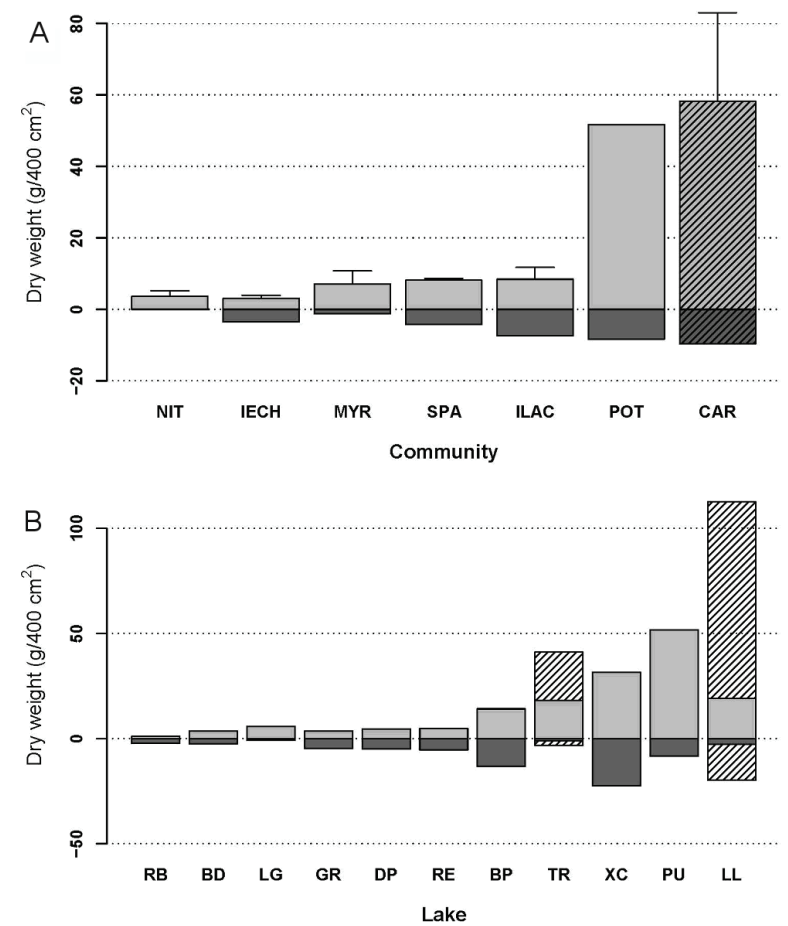

Fig. 2. Distribution of the average macrophyte biomass (above and belowground) for the different macrophyte communities (A) and for the different lakes (B). Hatched areas correspond to the biomass of the only helophyte, Carex rostrata; the rest correspond to submersed species. Data are in $\mathrm{g}$ DW $400 \mathrm{~cm}^{-2}$.
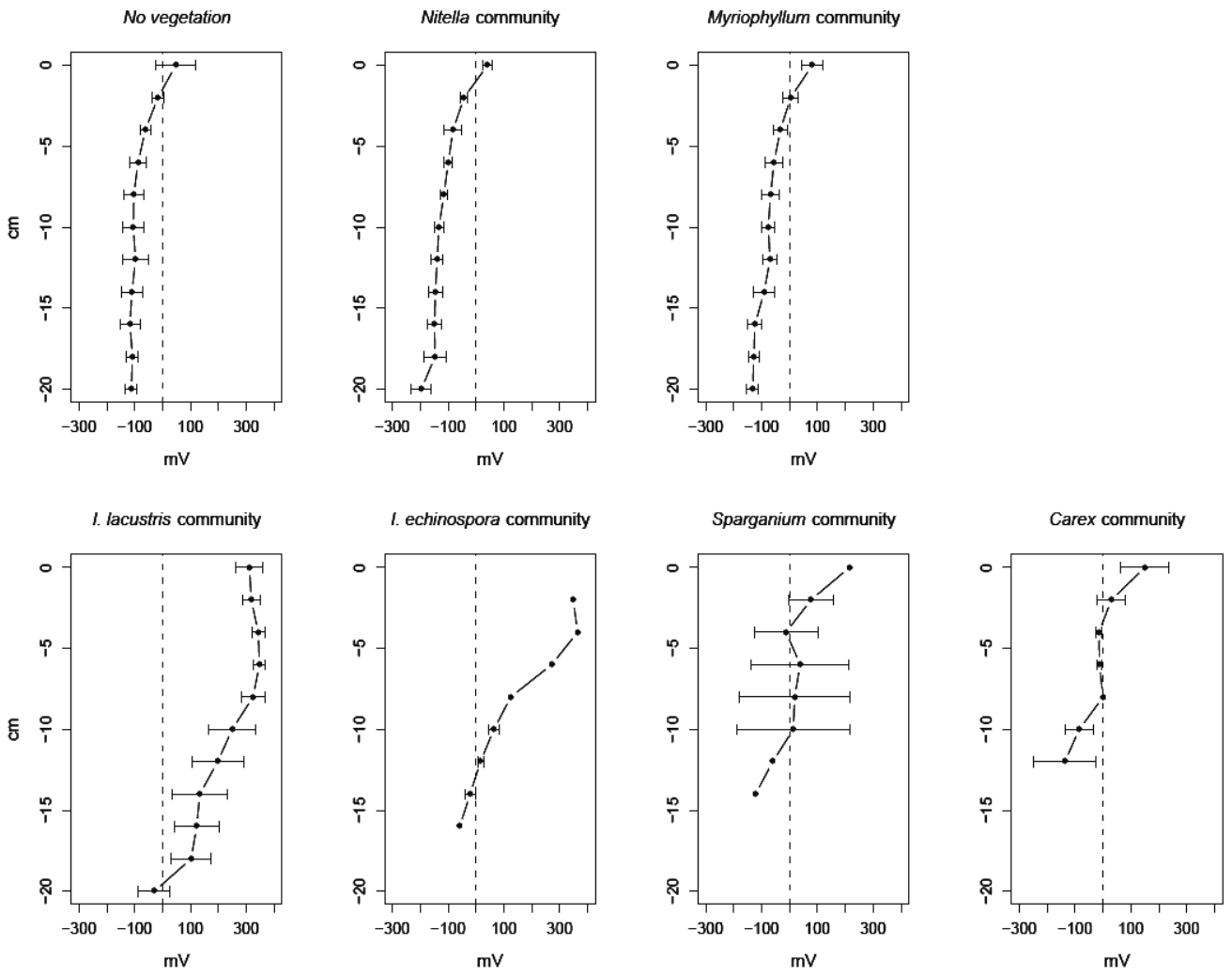

Fig. 3. Sediment redox profiles of the different macrophyte communities. Data are averages for sediments of the same communities across lakes. Profiles for each lake were already an average of at least two replicates. Error bars are standard deviations among communities. 


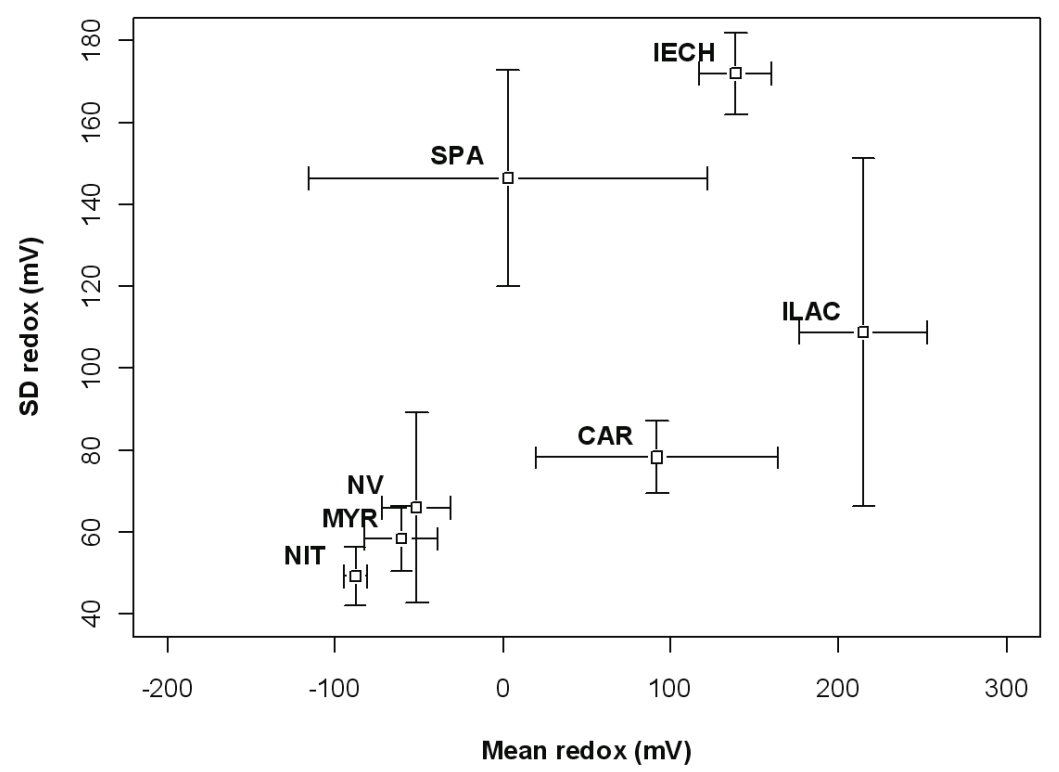

Fig. 4. Mean $v s$ standard deviation of the redox potential in the sediment of the different macrophyte communities. Data are averages from the water-sediment interface down to $-20 \mathrm{~cm}$. The codes for the macrophyte communities are the same than in figure 1 . Error bars are standard deviations among communities.

The patterns shown by the redox profiles in the different communities can be summarized by plotting the average and the standard deviation of the profiles in the upper $20 \mathrm{~cm}$ of the sediment (Fig. 4). We can thus distinguish a gradient from communities with high mean redox potential and strong deviation around this mean (I. lacustris and I. echinospora), communities with intermediate redox potentials in the sediment and also strong variation, and communities growing on very reduced sediments with rather low variance which show the same pattern than sediments without vegetation; Fig. 4).

Macrophyte biomass (total, above and/or belowground) did not relate to the mean or standard deviation of the redox potential in the sediment. There was, however, a negative exponential correlation between the mean redox potential and the above to belowground biomass ratio:

$$
\begin{gathered}
X_{\text {Redox }}=-116.4 \pm 25.0 \times \ln (A b / B w)+164 \pm 29.3 \\
p<0.0004
\end{gathered}
$$

where $X_{\text {Redox }}$ is the average redox potential from 0 down to $20 \mathrm{~cm}$ in the sediment and $A b / B w$ is the quotient of above $v s$ belowground biomass of the community.

Thus, the higher the underground biomass relative to the aboveground biomass, the more effective was the capacity of the community to oxidize the sediment. This pattern occurred regardless of the effect of Isoetes:

$$
\begin{aligned}
X_{\text {Redox }}=-83.8 \pm 22.6 & \times \ln (A b / B w)+93.1 \pm 31.8 \\
p & <0.005
\end{aligned}
$$

suggesting that, aside from the species-specific strategies of gas exchange within the root-sediment system, there are general patterns in the interaction between macrophytes and sediments.

\subsection{Dissolved nutrients}

\subsubsection{Sediment pore-water}

Nutrient concentration in sediment pore-water showed different patterns within macrophyte communities (Fig. 5). The samples from the I. lacustris community differed significantly from the rest (ANOSIM $p$ $<0.005$; Tab. 4) due to very low phosphate and high nitrate concentration (Figs $5 \mathrm{~b}$ and c). The sediment from the Carex community also differed from that of the Nitella and Sparganium (ANOSIM $p<0.005$; Tab. 4) due to low nitrate and high ammonia concentration (Figs 5c and d; Tab. 4). The Sparganium angustifolium community showed higher phosphates than the Myriophyllum alterniflorum community (Fig. 5b). As expected, nitrates dominated in oxidized sediments and ammonia in reduced ones, both forms of DIN showing mirrored behaviour (see Figs $5 \mathrm{c}$ and d). In contrast, phosphorus did not vary according to community composition (with the exception of low concentration in $I$. lacustris sediments) but depended on the general trophic state of the lake. Differences in nutrient concentrations, including phosphates, were also found between lakes (Tab. 5).

\subsubsection{Water column}

Nutrient concentrations in the water column clearly varied among lakes (ANOSIM $r=0.711 ; p<0.001$ ) and did not show similarities within samples of the same macrophyte communities (ANOSIM $r=-0.071 ; p$ $>0.75)$. 


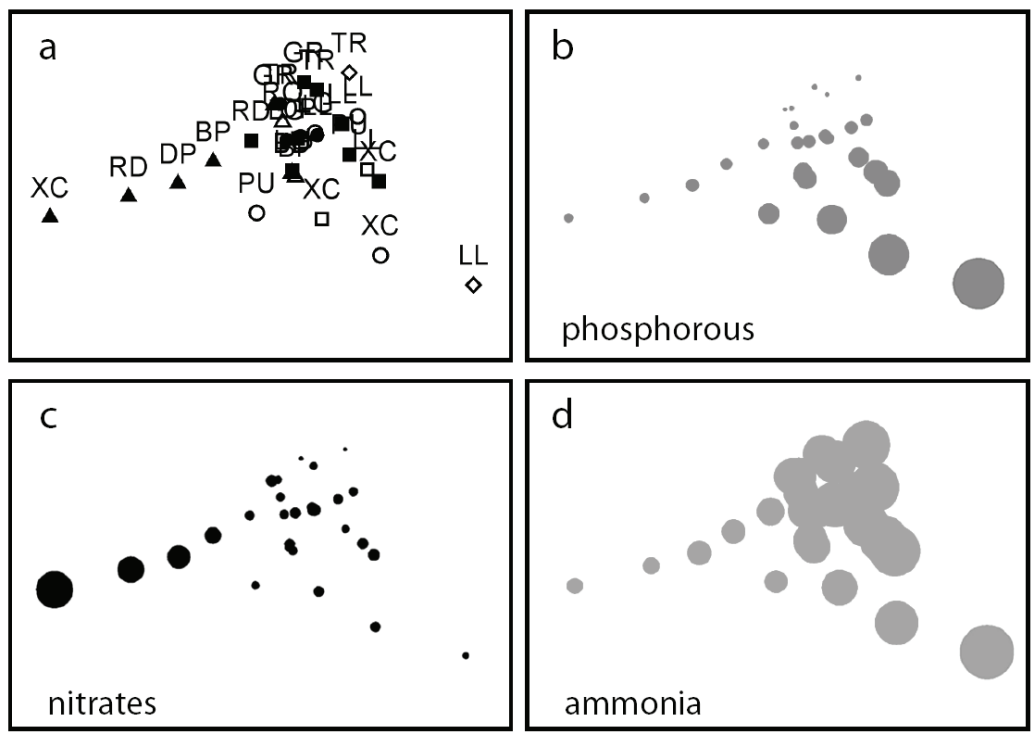

Fig. 5. Multi-Dimensional Scaling (MDS) plot for sediment pore-water nutrient concentrations in the different macrophyte communities. Data were normalised, square root-transformed average sediment concentrations from 0 down to $20 \mathrm{~cm}$.; a) corresponds to sample distribution with symbols as vegetation units and labels as lakes, b-d) are the same plot but with symbol size proportional to nutrient concentrations in pore-water: b) for phosphorus concentration, c) for nitrate concentration, and d) for ammonia concentration. Bubble areas are proportional to the transformed data. Stress $=0.05$.

Tab. 4. One-way ANOSIM pair-wise test for differences in sediment pore-water nutrient concentration between macrophyte communities. Significant differences are at $R=0.254$ (marked in bold) for $p<0.001$. The codes for the communities are: Ilac $=$ I.lacustris, Iechi $=$ I.echinospora, $\mathrm{Spa}=$ Sparganium, Car=Carex, Myr=Myriophyllum, Nit=Nitella, $\mathrm{NV}=$ without vegetation.

\begin{tabular}{lccccccc}
\hline & Iechi & Ilac & NV & Nit & Car & Myr & Spa \\
\hline Iechi & - & & & & & & \\
Ilac & $\mathbf{0 . 3 8 5}$ & - & & & & & \\
NV & -0.113 & $\mathbf{0 . 5 9 7}$ & - & & & & \\
Nit & -0.093 & $\mathbf{0 . 4 6 3}$ & 0.09 & - & & & \\
Car & $\mathbf{0 . 5 8 3}$ & $\mathbf{0 . 7 8 2}$ & $\mathbf{0 . 5 4 3}$ & 0.179 & - & & \\
Myr & 0.185 & $\mathbf{0 . 3 2 3}$ & -0.277 & -0.074 & $\mathbf{0 . 5 8 3}$ & - & \\
Spa & 0.583 & $\mathbf{0 . 6 3 6}$ & 0.220 & -0.429 & 0.000 & $\mathbf{0 . 9 1 7}$ & - \\
\hline
\end{tabular}

Tab. 5. Summary of a one-way ANOVA to test for differences in the average sediment pore-water nutrient concentration within lakes and within communities. $\mathrm{df}=$ degrees of freedom, $\mathrm{MS}=$ Mean square, $\mathrm{ns}=$ not significant at $p<0.01 . \mathrm{N}=2$ replicated sediment corers per community.

\begin{tabular}{llcccc}
\hline Variable & Source of variation & df & MS & F & $p$ \\
\hline \multirow{2}{*}{$\log \left[\mathrm{PO}_{4}\right]$} & Lakes & & & & \\
& Between & 10 & 1.28 & 9.69 & $<0.0001$ \\
$\log \left[\mathrm{NH}_{4}\right]$ & Within & 39 & 0.13 & & - \\
& Between & 10 & 0.21 & 3.04 & $<0.01$ \\
$\log \left[\mathrm{NO}_{3}+\mathrm{NO}_{2}\right]$ & Within & 39 & 0.07 & & - \\
& Witheen & 10 & 0.41 & 2.91 & $<0.01$ \\
& Communities & 39 & 0.14 & & - \\
$\log \left[\mathrm{PO}_{4}\right]$ & Between & 6 & & & \\
& Within & 43 & 0.80 & 2.60 & - \\
$\log \left[\mathrm{NH}_{4}\right]$ & Between & 6 & 0.30 & & - \\
& Within & 43 & 0.07 & 4.19 & $<0.01$ \\
$\log \left[\mathrm{NO}_{3}+\mathrm{NO}_{2}\right]$ & Between & 6 & 0.74 & 6.17 & $<0.0001$ \\
& Within & 43 & 0.11 & & - \\
\hline
\end{tabular}




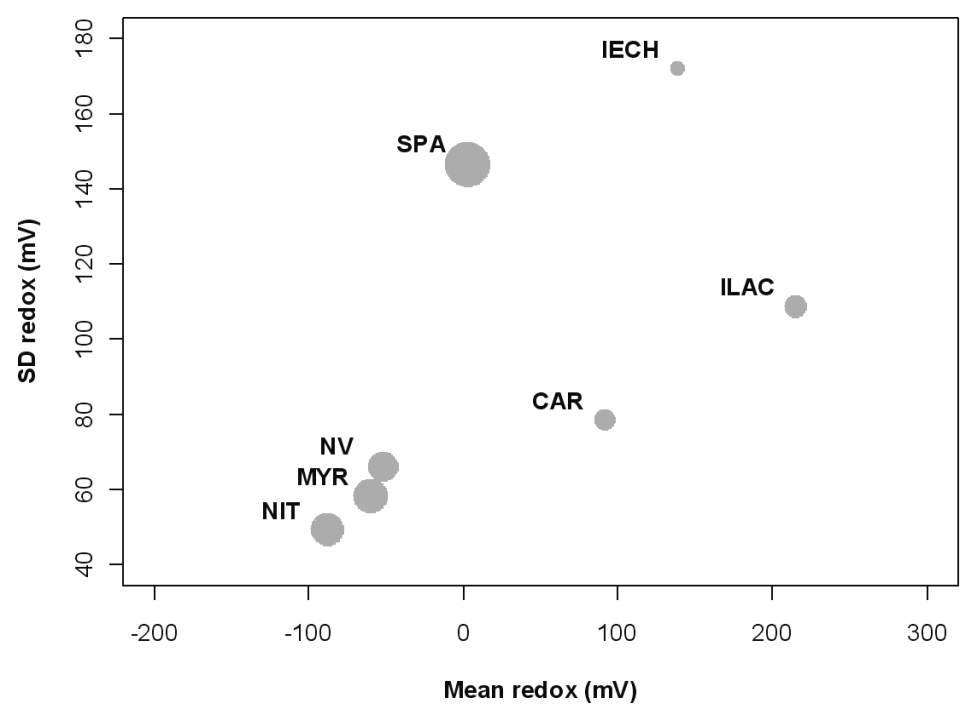

Fig. 6. Water column nitrate concentration (data in $\mu \mathrm{M}$ ) represented as the proportional area of the symbols in the plot of the average vs. the standard deviation of the sediment redox for the macrophyte communities of the studied lakes. The codes for the communities are: Ilac $=$ I.lacustris, Iechi $=$ I.echinospora, $\mathrm{Spa}=$ Sparganium, Car $=$ Carex, $\mathrm{Myr}=$ Myriophyllum, $\mathrm{Nit}=$ Nitella, $\mathrm{NV}=$ without vegetation .

Nonetheless, nitrate concentration tended to be lower in the water column overlying the isoetids communities compared to other communities, as shown by a bubble plot of porewater nitrate concentration on the plot of mean $v$ s standard error of sediment redox (Fig. 6). This is in apparent contradiction to the patterns of dissolved nitrates in the sediment pore-water (Fig. 5).

\section{DISCUSSION}

Composition and biomass of aquatic vegetation from the selected lakes grouped into seven distinct communities that can be characterized by dominance of different functional morphologies. The I. lacustris community represents the facies dominated by perennial isoetids. The I. echinospora community is characterised by annual isoetids. The communities with Myriophyllum and $P$. praelongus are dominated by elodeids and the community with Nitella is dominated by stoneworts that can be accompanied by elodeids, growing on more unstable sediments or at deeper waters. S. angustifolium forms a community dominated by rooted emergent vegetation and is usually found at shallow waters near water inflows or outflows. Finally, the Carex community corresponds to a helophytic belt.

The distribution of the communities among the lakes showed that in lakes with a single community, this is commonly an isoetid community, while lakes with elodeids and Carex also hold other communities. In the studied systems, the community of I. lacustris can be found together with any other of the communities while the community of I. echinospora only appeared mixed with that of I. lacustris.

Macrophyte biomass (aboveground and total) was rather similar within the different communities with the exception of extremely high values for the community with the helophyte $C$. rostrata, as expected from general patterns of macrophyte biomass and production within aquatic plant forms (Wetzel 2001). Also notorious was the significantly high biomass of the $P$. praelongus community in Lake Pudo, the system with the highest alkalinity, where this species is accompanied by Nitella sp. and $P$. perfoliatus. Since $P$. praelongus is found in medium to high mineralized waters, this result points towards water mineralization as a major factor controlling composition and biomass of the submersed vegetation in Pyrenean lakes (Gacia et al. 1994).

Within lakes, average submersed macrophyte biomass showed a broad range of variation (from 80 to $1500 \mathrm{~g} \mathrm{DW} \mathrm{m}^{-2}$ ), similar to ranges across trophic gradients (see compilation in Wetzel 2001). Thus, even if water nutrient concentrations are low in the Pyrenees, macrophyte vegetation can reach high biomass due to the relatively higher exposure irradiance in the Pyrenees compared to northern Europe (Gacia \& Ballesteros 1994). Values for the Carex community, although appearing at higher altitude ranges than in other alpine systems (Petraglia \& Tomaselli 2003), were within the range of helophytes for oligotrophic-softwater lakes.

In lake sediments, oxygen diffusion from the water column to the sediment is very low and results in reduced conditions a few $\mathrm{mm}$ below the interface (Sergei et al. 2006). The presence of submersed vegetation may contribute to both oxygenation and/or increase of the reducing power due to accumulation of organic matter. Our analysis of redox profiles shows how these combined effects can be predicted for the different macrophyte communities of the Pyrenees.

Rooted aquatic plants may release oxygen to the sediment to overcome phytotoxic compounds in flooded soils (Amstrong et al. 1991). Two main strategies to 
Tab. 6. Nutrient concentrations in pore-water sediments of lakes holding Isoetes communities compared to other macrophyte communities and/or areas without vegetation. DIN=Dissolved inorganic nitrogen. All data are in $\mu \mathrm{M}$.

\begin{tabular}{llcccc}
\hline Lake & Community & $\mathrm{PO}_{4}$ & $\mathrm{NH}_{4}$ & $\mathrm{NO}_{3}+\mathrm{NO}_{2}$ & $\mathrm{DIN}$ \\
\hline \multirow{2}{*}{ Baciver Petit } & I. echinospora & 13.5 & 167 & 13 & 180 \\
& I. lacustris & 3.7 & 84 & 44 & 128 \\
\multirow{5}{*}{ Granotes Petit } & unvegetated & 4.7 & 292 & 15 & 307 \\
& I. lacustris & 5.3 & 89 & 85 & 175 \\
\multirow{3}{*}{ Redó } & unvegetated & 1.8 & 225 & 7 & 232 \\
\multirow{3}{*}{ Xic } & I. lacustris & 1.2 & 208 & 23 & 231 \\
& unvegetated & 3.0 & 114 & 15 & 128 \\
& I. lacustris & 2.8 & 41 & 100 & 140 \\
& unvegetated & 24.6 & 405 & 23 & 428 \\
& Nitella & 53.4 & 292 & 16 & 308 \\
& I. lacustris & 2.6 & 36 & 217 & 253 \\
& S. angustifolium (mixed with I. lacustris) & 33.0 & 226 & 18 & 244 \\
\hline
\end{tabular}

fight sediment anoxia are developed: 1) superficial rooting, and 2) development of internal gas space for oxygen transport within the plant to the roots (see review in Amstrong 1982). Species of the genus Nitella and Myriophyllum are good representatives of the first group. Since they do not have roots or have short roots in contact with the sediment-water interface or directly with the water column, they do not influence the sediment on which they grow. The rest of the macrophytes studied here have significantly developed underground tissues (roots and possibly rhizomes) and thus exert a higher oxygen demand but may release oxygen from the roots to the sediment. This group of species modifies the sediment redox compared to areas without vegetation. Differences in the oxidative capacity of roots are related to root porosity (Justin \& Amstrong 1987) and plant productivity. Species of the genus Isoetes are the best representatives of this former strategy and show high radial oxygen loss (i.e., oxygen leakage into the sediment along the entire length of the root; see revision in Smolders et al. 2002). When comparing different Isoetes species, oxygen leaking is higher for that with the highest biomass and primary production (Gacia 1993). Coupled to the differences in red-ox potential, isoetid sediments show lower concentrations of dissolved inorganic carbon and $\mathrm{CO}_{2}$ in the upper sediment layers (i.e., the root zone) than deeper in the sediment (Boston \& Adams 1987). This pattern likely responds to both enhanced mineralization of the organic matter in the oxidative layers and isoetid exploitation of sedimentary $\mathrm{CO}_{2}$ for dark inorganic carbon fixation (i.e., CAM metabolism; Boston \& Adams 1985; Boston et al. 1987) as a strategy to overcome carbon limitation for photosynthesis in extreme soft-water systems.

Differences in community biomass did not explain the redox state of the sediment. However, the ratio between below and aboveground biomass appeared to be inversely correlated to the average sediment redox. This relationship was independent of the composition of the community and held true even when isoetids, which have a known oxidative capacity, were excluded, thus pointing to the existence of functional patterns of plantsediment interactions.

Coupling between macrophyte communities and their immediate environment (overlying water and sediment) was manifested mainly as the variation in pore-water nitrate concentrations among communities, which was associated to the presence of Isoetes. This, however, did not translate into a differential release of nitrate to the lake water, as shown by a lack of correlation between the concentration of nitrogen species in pore-water and in the water column. Nonetheless, water overlaying Isoetes communities tended to have lower nitrate, even within lakes were this community cooccurred with other macrophyte communities (i.e., lakes Baciver Petit, Dellui Petit and Xic; Tab. 6). The lower total DIN in the sediment pore-water of Isoetes communities clearly points to the possibility of net losses of nitrogen due to both denitrification in sediments with high redox gradients (Olsen \& Andersen 1994; Risgaard-Petersen \& Jensen 1997) and rapid uptake of DIN by both above and belowground plant compartments (Farmer 1990).

Variance among water column samples was clearly related to the trophic state of the lake, i.e., to the gradient from extremely oligotrophic systems and relatively more nutrient rich waters (with high ammonia and total dissolved phosphorus, TDP) and high TDP in the sediment. In contrast, plant communities explained hardly any variance among water samples. The extremely low nutrient concentrations in these systems and the rapid uptake by the vegetation (Andersen et al. 2005) may hide any differences among communities except for nitrate.

\section{CONCLUSIONS}

Based on species composition and biomass data we distinguished seven different macrophyte communities from the lakes studied. These communities are coupled to differences in sediment redox conditions and dominance of different forms of inorganic nitrogen in porewater. This, in turn, presumably results in different rates 
of mineralization of organic matter and nutrient recycling in lake sediments. These effects depend on the specific composition of the community, and on the allocation between above and belowground biomass, and are clearly manifested by sediment redox profiles from the water-sediment interface down to $20 \mathrm{~cm}$ into the sediment. In Pyrenean oligotrophic shallow lakes the interaction between macrophytes and the system occurs mainly through the sediment. This explains, at least in part, why studies looking for coupling between diversity of macrophytes and other trophic groups show weak or no association (Declerk et al. 2005). Macrophyte vegetation interferes in the mineralization of organic matter by modifying the oxidative capacity of the sediment, thus modulating nutrient recycling in lake sediments.

\section{ACKNOWLEDGEMENTS}

This study was funded by the Red de Parques Nacionales of the Spanish Ministry of the Environment (ref. 118/2003). We are thankful to Emma Cebrian and Jonatan Ortiz for their help with field work and to Maddi Altuna and Lluis Camarero for help in the processing of water samples.

\section{REFERENCES}

Amstrong, W. 1982. Waterlogged soils. In: J.R. Etherington, Environment and Plant Ecology. John Wiley and Son: 290-330.

Amstrong, W., S.H.F.H. Justin, P.M. Beckett \& S. Lythe. 1991. Root adaptation to soil watterlogging. Aquat. Bot., 39: 57-73.

Andersen, T., O. Pedersen \& F.Ø. Andersen. 2005. Nutrient concentrations in a Littorella uniflora community at higher $\mathrm{CO}_{2}$ concentrations and reduced light intensities. Freshwat. Biol., 50: 1178-1189.

Boston, H.L. \& M.S. Adams. 1985. Seasonal diurnal acid rhythms in two aquatic crassulacean acid metabolism plants. Oecologia, 65: 573-579.

Boston, H.L. \& M.S. Adams. 1987. Productivity, growth and photosynthesis of two small 'isoetid' plants, Littorella uniflora and Isoetes macrospora. J. Ecol., 75: 333-350.

Boston, H.L., M.S. Adams \& T.P. Pienkowski. 1987. Utilization of sediment $\mathrm{CO}_{2}$ by selected North American Isoetids. Ann. Bot., 60: 485-494.

Camarero, Ll., M. Rogora, R. Mosello, J. Anderson, A. Barbieri, I. Botev, M. Kernan, J. Kopácek, A. Korhola, A. Lotter, G. Muri, C. Postolache, E. Stuchlík, H. Thies \& R.F. Wright. (2009). Regionalisation of chemical variability in European mountain lakes. Freshwat. Biol:: (in press).

Chappuis, E., E. Gacia, J.L. Riera, E. Ballesteros, \& A. Lumbreras. 2008. Les plantes aquàtiques dels estanys del Parc Nacional d'Aigüestortes i Estany de Sant Maurici. El Portarró. In: Revista del Parc Nacional d'Aigüestortes $i$ Estany de Sant Maurici: 1-6.

Catalan, J., E. Ballesteros, L1. Camarero, M. Felip \& E. Gacia. 1992. Limnology in the pyrenean lakes. Limnetica, 8: 27-38.

Catalan, J., E. Ballesteros, E. Gacia, A. Palau \& L. Camarero. 1993. Chemical composition of disturbed and undisturbed high mountain lakes in the Pyrenees: a reference for acidified sites. Water Res., 27: 133-141.

Declerk, S., J. Vandekerkhove, L. Johansson, K. Muylaert, J.M. Conde-Porcuna, K. Van der Gucht, C. Pérez Martínez, T. Lauridsen, K. Schwenk, G. Zwart, W. Rommens, J. López-Ramos, E. Jeppesen, W. Vyverman, L.
Brendonck \& L. De Meester. 2005. Multi-group Diversity in shallow lakes along gradients of phosphorous and water plant cover. Ecology, 86(7): 1905-1915.

Engelhardt, K.A.M. \& M.E. Ritchie. 2001. Effects of macrophyte species richness on wetland ecosystem functioning and services. Nature, 411(6838): 687-689.

Enriquez, S., N. Marbà, C.M. Duarte, B. Tussenbroek \& G. Reyes-Zavala. 2001. Effects of seagrass Thalassia testudinum on sediment redox. Mar. Ecol. Progr. Ser., 219: 149-158.

Farmer, A.M. 1990. The effects of lake acidification on aquatic macrophytes: a review. Environ. Pollut., 65: 219240.

Farmer, A.M. \& M.S. Adams. 1989. A consideration of the problems of scale in the study of the ecology of aquatic macrophytes. Aquat. Bot., 33: 177-189.

Gacia, E. 1993. Ecologia dels Macròfits submergits dels estanys del Pirineu: estructura i dinàmica de les poblacions de l'Estany Baciver (Valh Aran). Ph.D, University of Barcelona, Barcelona: $176 \mathrm{pp}$.

Gacia, E. \& E. Ballesteros. 1994. Production of Isoetes lacustris in a Pyrenean lake: seasonality and ecological factors involved in the growing period. Aquat. Bot., 48: 77-89.

Gacia, E. \& E. Ballesteros. 1996. The effect of increased water level on Isoetes lacustris L. in Lake Baciver, Spain. J. Aquat. Plant Manage., 34: 57-59.

Gacia, E. \& E. Ballesteros. 1998. Effects of building up a dam in a shallow high mountain lake (Baciver, Central Pyrenees). Oecol. Aquat., 11: 55-66.

Gacia, E., E. Ballesteros, L1. Camarero, O. Delgado, A. Palau, J.L. Riera \& J. Catalan. 1994. Macrophytes from the Eastern Pyrenean lakes: composition and ordination in relation to environmental factors. Freshwat. Biol., 32: 73-81.

Heino, J. 2005. Functional biodiversity of macroinvertebrate assemblages along major ecological gradients of boreal headwater streams. Freshwat. Biol., 50(9): 1578-1587.

Janauer, G.A. 2001. Is what has been measured of any direct relevance to the success of the macrophyte in its particular environment?. J. Limnol., 60 (Suppl. 1): 33-38.

Justin, S.H.F.H. \& W. Amstrong. 1987. The anatomical characteristics of roots and plant response to soil flooding. New Phytol., 106: 465-495.

Levat, Y., P. Lasserre \& P. Le Corre. 1990. Seasonal changes in pore-water concentrations of nutrients and their diffusive fluxes at sediment-water interface. J. Exp. Mar. Biol. Ecol., 35: 135-160.

Margalef Mir, R. 1981. Distribución de los macrófitos de las aguas dulces y salobres del E y NE de España y dependencia de la composición química del medio. Fund. J. March Ser. Univ., 157: 1-62.

McClarke, K.R. \& R.N. Gorley. 2006. PRIMER v.6: User Manual/Tutorial: $189 \mathrm{pp}$.

Mosello, R., A. Lami, A. Marchetto, M. Rogora, B. Wathne, L. Lien, J. Catalan, L. Camarero, M. Ventura, R. Psenner, K. Koinig, H. Thies, S. Sommaruga-Wögrath, U. Nickus, D.Tait, B. Thaler, A. Barbieri \& R. Harriman. 2002. Trends in the chemical composition of high altitude lakes selected for the MOLAR project. Water Air Soil Poll., 2: 75-89.

Murphy, K.J. 2002. Plant communities and plant diversity in soft-water lakes of northern Europe. Aquat. Bot., 73: 287324.

Olsen, K.R. \& F.Ø. Andersen. 1994. Nutrient cycling in a shallow, oligotrophic Lake Kvie, Denmark. Hydrobiologia, 275/276: 255-265.

Pedersen, O., K. Sand-Jensen \& N.P. Revsbech. 1995. Diel pulses of $\mathrm{O}_{2}$ and $\mathrm{CO}_{2}$ in sandy lake sediments inhabited by Lobelia dortmanna. Ecology, 76: 1536-1545.

Petraglia, A. \& M. Tomaselli. 2003. Ecological profiles of wetland plant species in the northern Apennines (N. Italy). J. Limnol., 62(1):71-78. 
Risgaard-Petersen, N. \& K. Jensen. 1997. Nitrification and denitrification in the rizosphere of the aquatic macrophyte Lobelia dortmanna L. Limnol. Oceanogr., 42: 529-537.

Sagova, M., M.S. Adams \& M.G. Butler. 1993. Relationship between plant roots and benthic animals in three sediment types of a dimictic mesotrophic lake. Arch. Hydrobiol., 128(4): 423-436.

Sand Jensen, K. \& M. Sondergaard. 1979. Distribution and quantitative development of aquatic macrophytes in relation to sediment characteristics in oligotrophic Lake Kalgaard, Denmark. Freshwat. Biol., 9: 1-11.

Sand Jensen, K., C. Prahl \& H. Stockholm. 1982. Oxygen release from roots of submerged aquatic macrophytes. Oikos, 38: 349-353.

Received: August 2008

Accepted: November 2008
Sergei, K., I. Tsandev, I. L'Heureux \& D. Rancourt. 2006. Factors controlling long-term phosphorus efflux from lake sediments: Exploratory reactive-transport modelling. Chem. Geol., 234(1-2): 127-147.

Smolders, A.J.P., E.C.H.E.T. Lucassen \& J.G.M. Roelofs. 2002. The isoetid environment: biogeochemistry and threats. Aquat. Bot., 73: 325-350.

The MOLAR water chemistry group. 1999. The MOLAR project: atmospheric deposition and lake water chemistry. J. Limnol., 58: 88-106.

Wetzel R.G. 2001. Limnology, Lake and River Ecosystems. Academic Press, San Diego, CA, USA: 850 pp. 